\title{
Benefits of Power and Propulsion Technology for a Piloted Electric Vehicle to an Asteroid
}

\author{
Carolyn R. Mercer ${ }^{1}$, Steven R. Oleson ${ }^{2}$, Eric J. Pencil ${ }^{3}$, Michael F. Piszczor ${ }^{4}$, Lee S. Mason ${ }^{5}$ \\ Kristen M. Bury ${ }^{6}$, David H. Manzella ${ }^{7}$, Thomas W. Kerslake ${ }^{8}$, and Jeffrey S. Hojnicki ${ }^{9}$ \\ NASA Glenn Research Center, Cleveland, Ohio, 44135, USA \\ John P. Brophy ${ }^{10}$ \\ Jet Propulsion Laboratory, Pasadena, California, 91125, USA
}

\begin{abstract}
NASA's goal for human spaceflight is to expand permanent human presence beyond low Earth orbit (LEO). NASA is identifying potential missions and technologies needed to achieve this goal. Mission options include crewed destinations to LEO and the International Space Station; high Earth orbit and geosynchronous orbit; cis-lunar space, lunar orbit, and the surface of the Moon; near-Earth objects; and the moons of Mars, Mars orbit, and the surface of Mars. NASA generated a series of design reference missions to drive out required functions and capabilities for these destinations, focusing first on a piloted mission to a nearEarth asteroid. One conclusion from this exercise was that a solar electric propulsion stage could reduce mission cost by reducing the required number of heavy lift launches and could increase mission reliability by providing a robust architecture for the long-duration crewed mission. Similarly, solar electric vehicles were identified as critical for missions to Mars, including orbiting Mars, landing on its surface, and visiting its moons. This paper describes the parameterized assessment of power and propulsion technologies for a piloted solar electric vehicle to a near-Earth asteroid. The objective of the assessment was to determine technology drivers to advance the state of the art of electric propulsion systems for human exploration. Sensitivity analyses on the performance characteristics of the propulsion and power systems were done to determine potential system-level impacts of improved technology. Starting with a "reasonable vehicle configuration" bounded by an assumed launch date, we introduced technology improvements to determine the system-level benefits (if any) that those technologies might provide. The results of this assessment are discussed and recommendations for future work are described.
\end{abstract}

${ }^{1}$ Aerospace Engineer, Exploration Flight and Development Office, Member AIAA.

${ }^{2}$ Aerospace Engineer, Mission Design and Analysis Branch, Member AIAA.

${ }^{3}$ Aerospace Engineer, Space Science Projects Office, Associate Fellow AIAA.

${ }_{5}^{4}$ Electrical Engineer, Photovoltaics and Power Technologies Branch, Associate Fellow AIAA.

${ }_{6}^{5}$ Aerospace Engineer, Thermal Energy Conversion Branch.

${ }^{6}$ Electrical Engineer, Power Systems Engineering Branch.

${ }^{7}$ Aerospace Engineer, Space Propulsion Branch.

${ }^{8}$ Electrical Engineer, Power Systems Engineering Branch.

${ }^{9}$ Electrical Engineer, Power Systems Engineering Branch.

${ }^{10}$ Principal Engineer, Propulsion and Materials Engineering Section, Senior Member AIAA. 


\section{Introduction}

$\mathrm{N}$ ASA'S goal for human spaceflight is to expand permanent human presence beyond low Earth orbit (LEO). To achieve this goal, NASA is identifying potential missions and technologies needed to conduct those missions safely and cost effectively. Mission options include piloted destinations to LEO and the International Space Station (ISS); high Earth orbit and geosynchronous orbit; cis-lunar space, lunar orbit, and the surface of the Moon; nearEarth objects; and the moons of Mars, Mars orbit, and the surface of Mars. Through a process known as the Human Exploration Framework Team (HEFT) architecture planning, NASA generated a series of design reference missions to drive out required functions and capabilities for these destinations, focusing first on a piloted mission to a nearEarth asteroid. One conclusion from this exercise was that a solar electric propulsion (SEP) stage could significantly reduce mission cost by reducing the required number of heavy lift launches, and could increase mission reliability by providing a robust architecture for the long-duration piloted mission. Similarly, solar electric vehicles were identified as critical for missions to Mars, including orbiting Mars, landing on its surface, and visiting its moons. ${ }^{1}$

This paper describes the parameterized assessment of power and propulsion technologies for a piloted solar electric vehicle to a near-Earth asteroid. The objective of the assessment was to determine nominal impacts of technology improvements on vehicle-level mass and cost. One benefit of this vehicle-level approach is that it captures the interrelationships between multiple subsystems, rather than simply quantifying the mass savings from a technology on a single subsystem.

Details of the design reference mission and the concept vehicle are described, including key design choices and all propulsion and power variants. The key system-level impacts for each propulsion and power technology are summarized, along with the relative costs of developing these technologies and using them for flight hardware. Although the results are not definitive because the full breadth of design space was not explored nor were the design impacts of contingency operations, we believe that they are representative and provide insight into the relative benefits of power and propulsion technologies for solar electric vehicles of this class. This work can help guide technology development investments to enable future missions to near-Earth asteroids and beyond.

\section{Design}

Asteroid 2008-EV5 was chosen as the representative mission because it approaches Earth relatively soon and is sufficiently large to be of scientific and engineering interest. The launch opportunity for this destination is 2024 . Further details about this mission are described in Section II.A, as well as a concept vehicle created by a previous study. Our figures of merit and guiding design principles are described in Section II.B, and choices for the baseline vehicle are described in Section II.C. Oleson et al. provide a detailed description of the baseline vehicle and design methodology. ${ }^{2}$

\section{A. Design Reference Mission}

The scenario of interest requires a solar electric stage to transfer cargo from LEO to the Earth-Moon libration point L1 (E-M L1) and to transfer crew to and from the asteroid. The cargo consists of a crew transport vehicle, deep space habitat, and robotic exploration vehicle. A 100-metric-ton (mt) vehicle launches the SEP stage, cargo, and a kick stage; the kick stage raises the SEP stage with its cargo to a $400-\mathrm{km}$ circular orbit. The SEP stage brings the cargo to L1 and docks with a previously-positioned cryogenic propulsion stage and a crew transfer vehicle. The cryostage provides the high-thrust delta- $\mathrm{V}$ needed for Earth escape velocity and is then jettisoned. The SEP stage delivers the crew and cargo to the asteroid, and then propels the crew transport vehicle to a hyperbolic return to Earth. This operations concept is shown in Fig. 1. Note that this mission has two operational modes: an unpiloted mission from LEO to an Earth staging orbit, followed by a piloted mission up to the asteroid and return to Earth.

The primary constraints are a piloted trip time of 400 days or less to prevent excessive exposure to ionizing radiation, and mass and volume sufficiently small to permit the launch of the SEP stage together with other required vehicles in a single 100-mt launch vehicle.

For the initial assessment of this design reference mission, the HEFT developed an SEP stage concept design. Their design employed two planar solar array panels producing $320 \mathrm{~kW}$ at end of life (EOL) using $33 \%$ efficient cells; eight hall effect thrusters with $50 \mathrm{~kW}$ maximum power; a thruster boom to minimize plasma impingement on the arrays; xenon stored in eight cylindrical tanks; and a power processing unit cooled by heat pipe radiators. ${ }^{3}$ 


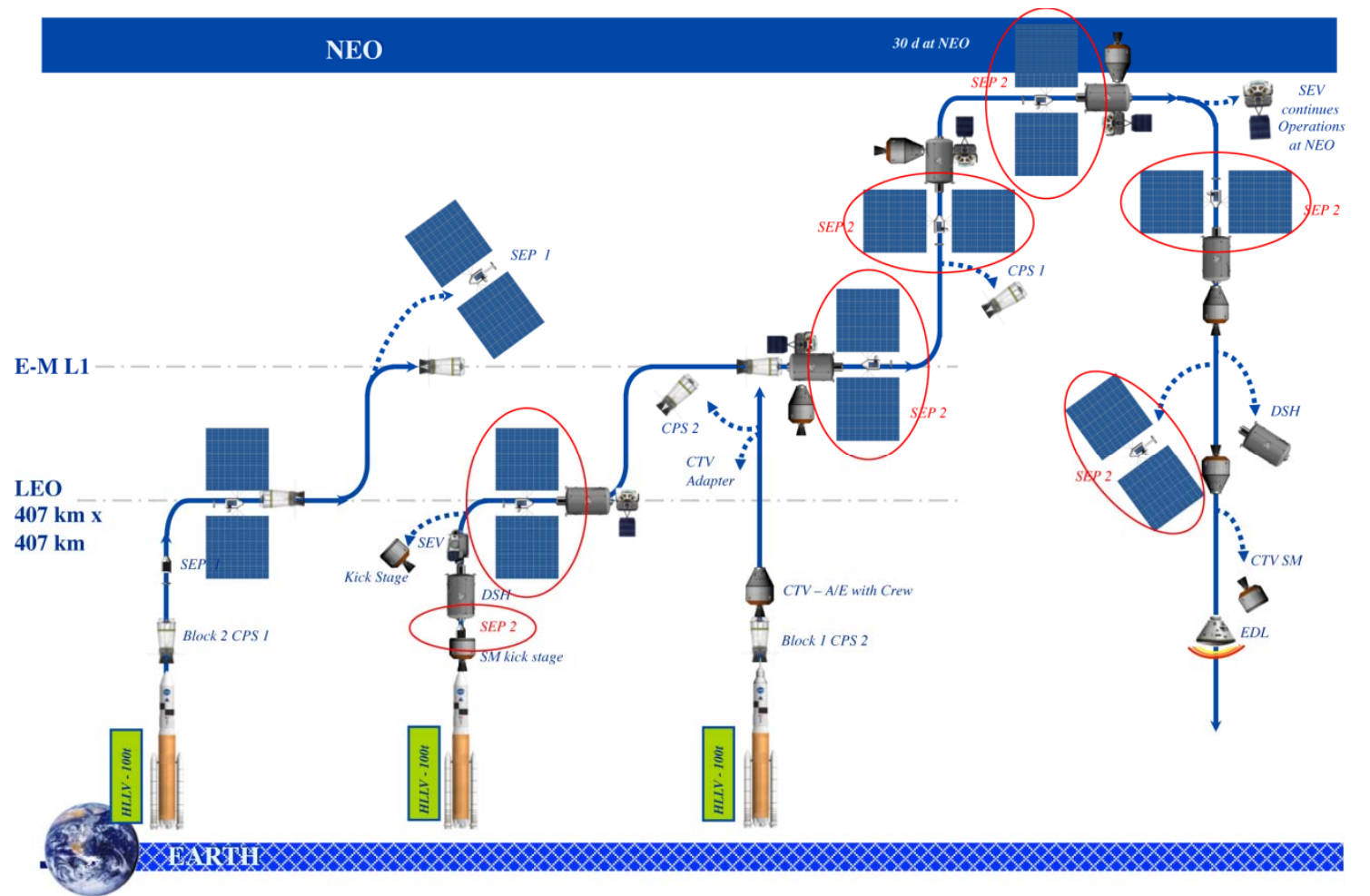

Figure 1. Concept of operations for a piloted mission to a near-Earth asteroid. ${ }^{1}$ The solar electric stage used for the crew (SEP2) is circled in red.

\section{B. Design Approach}

To conduct our parametric assessment of propulsion and power technologies, the Collaborative Modeling for Parametric Assessment of Space Systems (COMPASS) ${ }^{4}$ team at the NASA Glenn Research Center started with a clean sheet design using the following figures of merit:

- Safely deliver crew to/from asteroid

- Single fault tolerance to loss of crew and loss of mission

- Nominal mission time of 800 days with piloted trip time $<400$ days

- 2023 launch date

- Mass and volume

- $\quad 100$-mt launch vehicle with 8.5 - by 25 -m shroud

- Nominally $47 \mathrm{mt}$ allocated for SEP stage

- Performance

- Target $300 \mathrm{~kW}$ of power to the propulsion system

- Provide $15 \mathrm{~kW}$ of power to the payload (deep space habitat), except during eclipse

- Provide $5 \mathrm{~kW}$ of power for housekeeping loads

- Withstand cryogenic kick stage propulsive maneuvers up to 0.1 -g steady-state longitudinally and docking event loading up to $0.02 \mathrm{~g}$ longitudinally and $0.01 \mathrm{~g}$ transverse

- Low cost, simple, and robust

- Use commercial-off-the-shelf components when available

The spacecraft is designed to be single fault tolerant in the design of the subsystems, where possible. Exceptions to this include the electric power system, propellant tanks, and radiators that have zero fault tolerance, although they are designed to accommodate some performance degradation. Note that because contingency operations are not included in this analysis, conclusions about the relative merits of parameterized power and propulsion technologies must be treated as preliminary. 
Mass growth calculations were conducted according to AIAA S-120-2006, "Standard Mass Properties Control for Space Systems." The percent growth factors specified in this standard were applied to each subsystem before an additional growth was carried at the system level to ensure an overall growth of at least $30 \%$ on the dry mass of the entire system. Growth in the propellant mass was carried in the propellant calculation. A 30\% growth factor on the bottoms-up power requirements for the bus subsystems was used, with a $5 \%$ margin for the electric thruster power requirements.

The Spacecraft N-body Analysis Program ${ }^{5}$ was used to conduct a tangential steering spiral from LEO to 150,000-km semi-major axis (approximately the same energy state as E-M L1). The Mission Analysis Low-Thrust Optimization interplanetary low-thrust trajectory optimization tool $^{6}$ was used to determine the propellant mass needed to perform the heliocentric phase of the mission.

Vendor-supplied data was used where possible for mass and volume estimates to provide realism. This does not imply endorsement of any particular commercial system.

\section{Baseline Vehicle}

Following this design approach of using the simplest, most mature technology that can meet design objectives, we selected an array of nominally $30-\mathrm{kW}$ Hall thrusters and planar solar arrays with $33 \%$ efficient inverted metamorphic cells for the baseline configuration. Boom-mounted arrays are notched to provide a $45^{\circ}$ "keep away" zone from the thrusters' plumes. This design eliminates the need for power and propellant transport to boommounted thrusters. Power from the arrays is delivered to the thrusters using a direct-drive configuration ${ }^{7}$ rather than a conventional power processing unit, with both the arrays and thrusters operating at nominally $300 \mathrm{~V}$. Power processing and voltage levels were varied during the parameterization, as was solar cell efficiency.

This mission has two phases-an unpiloted rise to E-M L1 and a piloted transit to the asteroid and back. For this thrust class, a spiral trajectory is required for the initial phase, followed by a heliocentric trajectory for the second.

A total of 10 thrusters were used, each operating at nominally $30 \mathrm{~kW}$. If a thruster string fails, the piloted mission can still be completed by reducing some of the nominally planned coast time. The specific impulse (Isp) was set to $2000 \mathrm{sec}$ to match the Hall thrusters to the 300 -VDC direct-drive solar array output, and as a conservative trade between trip time and propellant mass. To a certain extent, the Isp can be increased to reduce the propellant mass for variants that would otherwise exceed the mass allocation. This option is limited for direct-drive architectures with solar arrays, however, as the thrusters must match the array voltage. Even higher Isp is required for nuclear power systems because of their higher inert mass, but this is possible because of the corresponding high alternating current (AC) voltage output from the power system. For either solar or nuclear systems, a higher Isp (at fixed power) will reduce interplanetary coast times and require longer Earth spiral mission times. The Earth spiral is unpiloted so a longer trip time for this portion is likely acceptable. Reduced coast times for the piloted heliocentric transfer phase might be undesirable once abort scenarios are assessed.

Xenon was chosen as the propellant because its low ionization energy enables high thruster efficiency and is more easily stored than other heavy noble gases. A single, spherical composite overwrap pressure vessel (COPV) xenon tank at 1200 psi was selected as the baseline; the number of tanks and storage conditions were traded as part of the parameterization.

Exposure to the Van Allen belt and scattered ions from the Hall thruster plumes is expected to degrade the solar arrays; we assumed an $18.8 \%$ EOL degradation from these sources when sizing the arrays. No damage was assumed to occur in heliocentric space. As the array voltage degrades, the current is adjusted altering the thruster mass flow rate to maintain a fixed specific impulse.

"No-roll" steering was chosen to eliminate the considerable mass of control moment gyroscopes and as a result, we accepted secondary axis Sun pointing errors and the attendant power loss. Since only one revolute axis is available for tracking, the arrays are revolved to minimize the Sun off-pointing angle while under thrust. Array tracking is controlled with ISS-derived Solar Alpha Rotary Joint (SARJ) gimbals, with mass reduced by removing the ISS in-flight servicing requirement. Our assumed launch date was favorable for the use of no-roll steering because the maximum angle between the arrays and Sun occurs early in the spiral trajectory, when the beginning-oflife (BOL) power is still available. This beta angle may occur later in the trajectory for different launch dates, requiring either oversized arrays or longer trip times because of the reduced power. Four RCS thruster pods provide roll, pitch, and yaw control, augmented by four gimbaled Hall thrusters.

Body-mounted radiators located directly below the solar array gimbals provide the best view for thermal rejection since they point roughly perpendicularly to the Sun's direction. All components of the thermal system were sized for the worst-case environmental conditions (LEO), with no redundancy. Micrometeoroid and orbital debris shielding was used to protect critical systems such as the propellant tanks and exposed heat pipes. The thrusters are recessed into the cylindrical structure to provide protection. Shielding by the aluminum structure is expected to be 
sufficient to protect electronics from radiation. The composite thrust tube design was sized to carry the mass of the deep space habitat and space exploration vehicle during launch. All communications are assumed to be performed by the deep space habitat, including relaying housekeeping commands and data for the SEP module.

This baseline SEP stage is shown in Fig. 2 and the key design features are listed in Table 1. Note that a rollout solar array based on mass and structure data provided by Deployable Space Systems, Inc. (DSS) was used as the baseline in part because other NASA studies have used structures based on data provided by other vendors. ${ }^{8}$ NASA relies on vendor-provided data to add realism to these concept designs and does not endorse any particular approach.

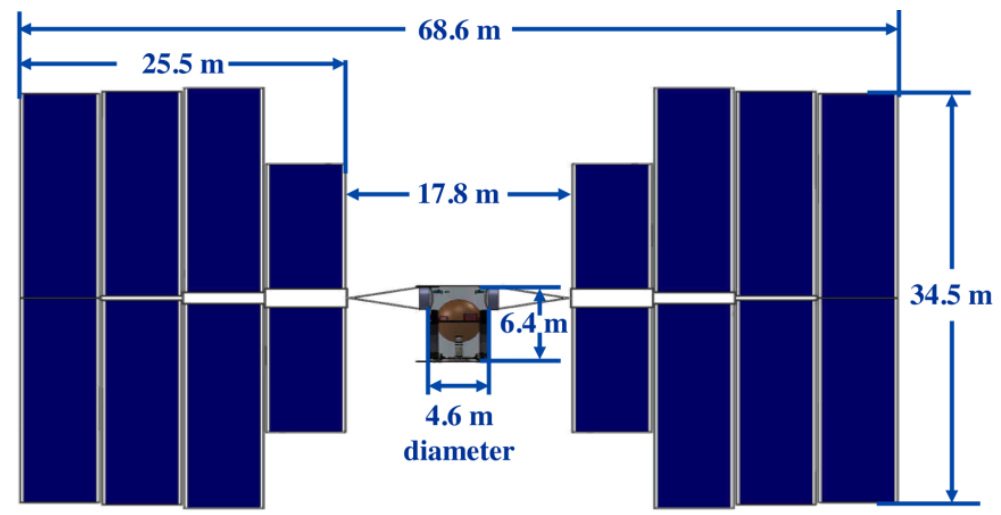

Figure 2. Solar electric propulsion stage—baseline configuration.

\begin{tabular}{|c|c|}
\hline S/C Element & Description \\
\hline Mission/Operations & $\begin{array}{l}\text { Phase 1: } \sim 1 \text { year unpiloted spiral to Earth-Moon L1, } \sim 6 \mathrm{~km} / \mathrm{s} \\
\text { Phase } 2:<400 \text { days piloted heliocentric transit to NEO } 2008-E V 5, \sim 4 \mathrm{~km} / \mathrm{s} \\
\sim 10 \mathrm{~km} / \mathrm{s} \text { Total } \Delta \mathrm{V}\end{array}$ \\
\hline Launch & 100-mt heavy lift launch vehicle with 8.5 - by 25 -m shroud \\
\hline Design Margins & $\begin{array}{l}\text { - } 10 \% \text { launch margin, } 30 \% \text { power growth except thrusters }(5 \% \text { power growth) } \\
\text { - } 5 \% \text { propellant margins, } 95 \% \text { SEP duty cycle } \\
\text { - Growth added to reach system level } 30 \%\end{array}$ \\
\hline $\begin{array}{l}\text { Guidance, } \\
\text { Navigation, and } \\
\text { Control (GN\&C) }\end{array}$ & $\begin{array}{l}\text { Star trackers, inertial measurement units (IMUs), monopropellant reaction control system } \\
\text { (RCS), no-roll steering during spiral }\end{array}$ \\
\hline Power & $\begin{array}{l}381 \mathrm{~kW} \text { BOL, } 300 \mathrm{~V} \text { planar solar arrays with } 33 \% \text { efficient cells, arrays notched to avoid } \\
45^{\circ} \text { thruster plume }\end{array}$ \\
\hline Propulsion & $\begin{array}{l}\text { Ten 30-kW Hall thrusters using direct drive at } 2000 \mathrm{sec} \text { Isp, four thrusters gimbaled; one } \\
\text { 3-m-diameter COPV xenon tank }\end{array}$ \\
\hline $\begin{array}{l}\text { Structures and } \\
\text { Mechanisms }\end{array}$ & Composite thrust tube; ISS-derived solar array gimbals \\
\hline Communications & All communications assumed to reside on Deep Space Hab vehicle \\
\hline $\begin{array}{l}\text { Command and Data } \\
\text { Handling (C\&DH) }\end{array}$ & Shielded system to control SEP module, housekeeping relayed by habitat \\
\hline Thermal & $\begin{array}{l}\text { Simple body-mounted radiators, } \sim 350 \mathrm{~kg} \text { of micrometeoroid orbital debris (MMOD) } \\
\text { shielding }\end{array}$ \\
\hline
\end{tabular}




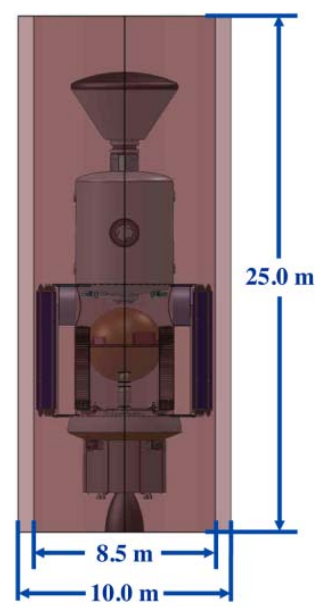

Figure 3. Launch configuration.

Table 2. Launch masses of each element in mission.

\begin{tabular}{|l|c|}
\hline \multicolumn{1}{|c|}{ Element } & Mass (mT) \\
\hline Space Exploration Vehicle & 6.7000 \\
\hline Deep Space Hab & 24.363 \\
\hline Solar Electric Propulsion Stage & 46.985 \\
\hline Service Module Kick Stage & 8.173 \\
\hline Launch Vehicle Adapter & 2.095 \\
\hline Cargo Element & 88.316 \\
\hline Margin & 1.684 \\
\hline Cargo Element With Margin & 90.000 \\
\hline Manager's Reserve & 10.000 \\
\hline $\begin{array}{l}\text { Heavy Lift Launch Vehicle } \\
\text { (HLLV) Lift Capability }\end{array}$ & 100.00 \\
\hline
\end{tabular}

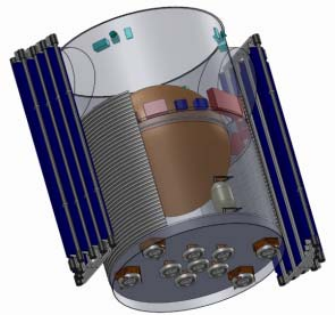

Figure 4. Baseline vehicle in stowed configuration.

The baseline configuration configured for launch is shown in Fig. 3 and in its stowed position is shown in Fig. 4. The cargo elements from bottom to top are kick stage, SEP stage, deep space habitat, and space exploration vehicle. The adapter to join the kick stage to the launch vehicle is not shown. Table 2 lists the nominal masses for each element as determined by the HEFT architecture study.

\section{Parametric Assessments of Power and Propulsion}

The baseline vehicle employed $300 \mathrm{~V}$ planar solar arrays with $33 \%$ efficient cells producing $381 \mathrm{~kW}$ at BOL. Four power variants were studied to determine their effect on vehicle mass and cost: planar arrays versus $2 \mathrm{X}$ concentrator arrays; $300 \mathrm{~V}$ versus $120 \mathrm{~V}$ arrays; solar cell efficiencies ranging from $29 \%$ to $37 \%$; and a nuclear fission reactor versus a solar array.

The baseline vehicle employed ten $30-\mathrm{kW}$ thrusters, direct-drive power management, and a single xenon tank. Four propulsion variants were studied to determine their effect on vehicle mass and cost: ten $30-\mathrm{kW}$ thrusters versus seven 50-kW thrusters; direct-drive versus power processor units (PPUs); a single xenon tank versus four tanks; and supercritical versus cooled supercritical xenon storage.

A summary of each variant is provided in Table 3, showing each case's configuration, trip time, inert mass, propellant mass, and wet mass with growth. The percentage dry mass savings for each variant is presented as compared to the case based on a planar array operating at the lowest voltage with a conventional power processing unit. Note that while the inert mass of the nuclear powered system (Case VIII) is larger than the solar power systems, the total launch masses are comparable. Note further that the wet mass for any configuration must not exceed the total amount allocated for the SEP stage plus margin $(48.669 \mathrm{mt})$ listed in Table 2, and should properly allow $\sim 4 \mathrm{mt}$ of margin for a target SEP stage wet mass of $44.7 \mathrm{mt}$. A description of each variant is provided in the following two sections. Full details can be found in the COMPASS final reports by Oleson et al., ${ }^{2,9}$ 


\section{A. Power Trades}

The following four power parameters were studied to determine vehicle mass and cost impacts: solar concentrator versus planar arrays, voltage level, cell efficiency, and power source.

The planar array used in the baseline vehicle described in Section II.C assumed 33\% efficient cells provided $381 \mathrm{~kW}$ at BOL to provide $300 \mathrm{~kW}$ to the thrusters and $20 \mathrm{~kW}$ for the deep space habitat and housekeeping loads at EOL. Array dimensions are shown in Fig. 2. Array mass and stowed volume data were obtained from DSS, Inc., and the vehicle based on this array was found to fit within the launch vehicle and complete the mission on time. The mass of this baseline power subsystem is shown in Table 3 as Case I.

Changing the bus voltage to $120 \mathrm{~V}$ has two primary impacts: the harness mass increases to accommodate higher currents and the use of conventional power processing units becomes required because of the thrusters' narrow operating voltage range. As shown in Table 3, Case IIIa, these changes resulted in a vehicle that did not fit the mass requirement for launch. A 120-V SEP stage can be built for this mission, however, by increasing the specific impulse to $2100 \mathrm{sec}$ thereby reducing the mass of xenon propellant. As shown in Table 3, Case IIIb, this increases the trip duration by 64 days over the baseline, although the piloted portion is only increased by 3 days and fits within the 400-day constraint.

Table 3. Summary of propulsion and power variants. Primary variants are shown in red for each case. Piloted portion of trip is heliocentric phase.

\begin{tabular}{|c|c|c|c|c|c|c|c|c|c|}
\hline & Case I & Case II & Case Illa & Case IIIb & Case IV & Case V & Case VI & Case VII & Case VIII \\
\hline Common elements & \multicolumn{9}{|c|}{$\begin{array}{c}300 \mathrm{kWe} \text { power to thrusters, four gimballed thrusters, supercritical Xenon storage, monopropllant RCS thrusters, radiation shielded electronics, } \\
\text { no-roll steering during spiral out }\end{array}$} \\
\hline $\begin{array}{l}\text { Spacecraft Bus } \\
\text { Voltage }\end{array}$ & 300 VDC & $300 \mathrm{VDC}$ & 120 VDC & $120 \mathrm{VDC}$ & $300 \mathrm{VDC}$ & $300 \mathrm{VDC}$ & $300 \mathrm{VDC}$ & $300 \mathrm{VDC}$ & 500 VAC \\
\hline $\begin{array}{l}\text { Power Processing } \\
\text { Unit }\end{array}$ & DDU & PPU & PPU & PPU & DDU & DDU & DDU & DDU & DDU \\
\hline Radiators* & Body mounted & Folded out & Folded out & Folded out & Body mounted & Body mounted & Body mounted & Body mounted & $\begin{array}{l}\text { Body Mounted \& } \\
\text { Folded out }\end{array}$ \\
\hline $\begin{array}{l}\text { Power Plant } \\
\text { description } \\
\text { (power level is } \\
\text { BOL) }\end{array}$ & $\begin{array}{c}381-k W \text { Planar } \\
\text { Solar Array with } \\
33 \% \text { efficient } \\
\text { cells }\end{array}$ & $\begin{array}{c}\text { 394-kW Planar } \\
\text { Solar Array with } \\
33 \% \text { efficient } \\
\text { cells }\end{array}$ & $\begin{array}{c}\text { 399-kW Planar } \\
\text { Solar Array with } \\
33 \% \text { efficient } \\
\text { cells }\end{array}$ & $\begin{array}{c}\text { 399-kW Planar } \\
\text { Solar Array with } \\
33 \% \text { efficient } \\
\text { cells }\end{array}$ & $\begin{array}{l}\text { Concentrator } \\
\text { array }(2 \mathrm{X}) \text { with } \\
33 \% \text { efficient } \\
\text { cells }\end{array}$ & $\begin{array}{c}381-\mathrm{kW} \text { Planar } \\
\text { Solar Array with } \\
33 \% \text { efficient } \\
\text { cells }\end{array}$ & $\begin{array}{c}\text { 381-kW Planar } \\
\text { Solar Array with } \\
\begin{array}{c}33 \% \text { efficient } \\
\text { cells }\end{array}\end{array}$ & $\begin{array}{c}\text { 381-kW Planar } \\
\text { Solar Array with } \\
33 \% \text { efficient } \\
\text { cells }\end{array}$ & $\begin{array}{c}\text { Fission reactor } \\
\text { with Brayton } \\
\text { power } \\
\text { convertors }\end{array}$ \\
\hline $\begin{array}{l}\text { Propulsion } \\
\text { description }\end{array}$ & $\begin{array}{l}\text { Ten } 30-\mathrm{kW} \text { Hall } \\
\text { thruster strings } \\
\text { (no spares) }\end{array}$ & $\begin{array}{l}\text { Ten } 30-k W \text { Hall } \\
\text { thruster strings } \\
\text { (no spares) }\end{array}$ & $\begin{array}{c}\text { Ten 30-kW Hall } \\
\text { thruster strings } \\
\text { (no spares) }\end{array}$ & $\begin{array}{l}\text { Ten } 30-\mathrm{kW} \text { Hall } \\
\text { thruster strings } \\
\text { (no spares) }\end{array}$ & $\begin{array}{c}\text { Ten } 30-\mathrm{kW} \text { Hall } \\
\text { thruster strings } \\
\text { (no spares) }\end{array}$ & $\begin{array}{c}\text { Seven } 50-k W \\
\text { Hall thruster } \\
\text { strings } \\
\text { (1 spare) }\end{array}$ & $\begin{array}{l}\text { Ten } 30-\mathrm{kW} \text { Hall } \\
\text { thruster strings } \\
\text { (no spares) }\end{array}$ & $\begin{array}{l}\text { Ten } 30-\mathrm{kW} \text { Hall } \\
\text { thruster strings } \\
\text { (no spares) }\end{array}$ & $\begin{array}{c}\text { Ten } 30-k W \text { Hall } \\
\text { thruster strings } \\
\text { (no spares) }\end{array}$ \\
\hline $\begin{array}{l}\text { Propellant storage } \\
\text { description }\end{array}$ & $1 \mathrm{COPV}$ tank & $1 \mathrm{COPV}$ tank & $1 \mathrm{COPV} \operatorname{tank}$ & $1 \mathrm{COPV}$ tank & $1 \mathrm{COPV}$ tank & $1 \mathrm{COPV}$ tank & 4 COPV tanks & $\begin{array}{l}4 \text { COPV tanks, } \\
\text { actively cooled }\end{array}$ & $1 \mathrm{COPV}$ tank \\
\hline $\begin{array}{l}\text { Isp (seconds) } \\
\text { Total Trip }\end{array}$ & 2000 & 2000 & 2000 & $2100^{x \pi}$ & 2000 & 2000 & 2000 & 2000 & $2640^{x x}$ \\
\hline $\begin{array}{l}\text { Spiral Out Trip Time } \\
\text { (days) }\end{array}$ & 340 & 381 & 398 & 401 & 340 & 339 & 357 & 351 & 358 \\
\hline $\begin{array}{l}\text { Heliocentric Trip } \\
\text { Time (days) }\end{array}$ & 383 & 383 & 386 & 386 & 384 & 384 & 386 & 385 & 386 \\
\hline $\begin{array}{l}\text { Total Trip Time } \\
\text { (days) }\end{array}$ & 723 & 764 & 784 & 787 & 724 & 723 & 742 & 736 & 744 \\
\hline \multicolumn{10}{|l|}{$\begin{array}{c}\text { System Mass } \\
\text { Summaries (kg) }\end{array}$} \\
\hline $\begin{array}{l}\text { Power subsystem } \\
\text { mass (with growth) }\end{array}$ & 3,330 & 3,370 & 4,647 & 4,647 & 3,135 & 3,330 & 3,330 & 3,336 & 9,365 \\
\hline $\begin{array}{l}\text { Propulsion } \\
\text { subsystem mass } \\
\text { (with growth) }\end{array}$ & 2,535 & 3,296 & 3,317 & 3,262 & 2,553 & 2,898 & 3,657 & 2,685 & 2,829 \\
\hline $\begin{array}{l}\text { Total Inert mass } \\
\text { (with system level } \\
\text { growth, and } \\
\text { residualmargin } \\
\text { propellant) }\end{array}$ & 12,211 & 13,365 & 14.961 & 14,466 & 12,023 & 12,628 & 14,014 & 13,072 & 16.951 \\
\hline $\begin{array}{l}\text { Total Used } \\
\text { Propellant } \\
\text { (Xe and RCS) }\end{array}$ & 34,150 & 34,933 & 35,794 & 33.530 & 33.955 & 33.945 & 35,144 & 34,393 & 29,771 \\
\hline $\begin{array}{c}\text { Total wet mass } \\
\text { with all Growth } \\
(\mathrm{kg})\end{array}$ & 46,361 & 48,298 & 50,755 & 47,996 & 45,978 & 46,572 & 49,158 & 47,465 & 46,722 \\
\hline $\begin{array}{l}\text { Mass margin }(\mathrm{kg}) \\
\text { (48,669 } \mathrm{kg} \\
\text { allocation) }\end{array}$ & 2,308 & 371 & $(2,086)$ & 673 & 2.691 & 2,097 & (489) & 1.204 & 1.947 \\
\hline $\begin{array}{l}\text { Inert Mass Savings } \\
\text { (compared to Case } \\
\text { llla) }\end{array}$ & $18 \%$ & $11 \%$ & & - & $20 \%$ & $16 \%$ & $6 \%$ & $13 \%$ & $-13 \%$ \\
\hline
\end{tabular}

${ }^{*}$ Radiators were configured as needed for each case.

**Isp was increased to meet mass target. 
The impact on vehicle mass from varying the cell efficiencies is shown in Table 4. As would be expected, higher efficiency cells reduce the overall mass of the vehicle by directly reducing the area of the array. For each kilogram of mass reduction in the dry vehicle, $0.5 \mathrm{~kg}$ of xenon propellant is saved, as well as $0.5 \mathrm{~kg}$ of chemical propellant for the cryopropulsion stage. The savings of going to $35 \%$ cells from $33 \%$ cells is $166 \mathrm{~kg}$ of inert mass (with growth), and therefore about $249 \mathrm{~kg}$ of total SEP wet mass. When considering the impact of cell efficiency, higher values are always better from a mass perspective. However, as shown in Fig. 7, the single largest cost of a SEP stage is the solar arrays, and the largest cost component of the arrays is the cells. Therefore, we looked to see if our mission goals could be met with lower cost, lower efficiency cells. As shown in Table 4, cells with $29 \%$ efficiency should be good enough to meet the vehicle mass target and could substantially reduce vehicle cost.

Table 4. Cell efficiency trade.

\begin{tabular}{|c|c|c|c|c|}
\hline \multirow[b]{2}{*}{ Cell Efficiency } & \multicolumn{4}{|c|}{ Mass with Growth $(\mathrm{Kg})$} \\
\hline & $29 \%$ & $33 \%$ & $35 \%$ & $37 \%$ \\
\hline \multicolumn{5}{|l|}{ Battery System } \\
\hline Battery Assembly-Secondary & 163 & 163 & 163 & 163 \\
\hline \multicolumn{5}{|l|}{ Power Management \& Distribution } \\
\hline High Voltage PDU & 181 & 181 & 181 & 181 \\
\hline Low Voltage PDU & 62 & 62 & 62 & 62 \\
\hline DC - DC Converter & 107 & 107 & 107 & 107 \\
\hline Array Regulator & 373 & 373 & 373 & 373 \\
\hline \multicolumn{5}{|l|}{ Solar Array Power System } \\
\hline PV Blanket & 1461 & 1279 & 1160 & 1070 \\
\hline On wing structure & 369 & 304 & 266 & 240 \\
\hline Phasing Structure & 356 & 356 & 356 & 356 \\
\hline Harness & 262 & 227 & 217 & 199 \\
\hline \multicolumn{5}{|l|}{ Power Cable and Harness Subsystem } \\
\hline Spacecraft Bus Harness & 280 & 278 & 278 & 277 \\
\hline Total Power System Mass (kg) & 3,614 & 3,329 & \begin{tabular}{|l|}
3,163 \\
\end{tabular} & 3,028 \\
\hline TOTAL SEP WET MASS $(\mathbf{k g})$ & 46,788 & 46,361 & \begin{tabular}{|l|}
46,112 \\
\end{tabular} & 45,909 \\
\hline
\end{tabular}

A $2 \mathrm{X}$ concentrator array based on "pop-up" flexible reflectors was designed to reduce the total area of photovoltaic cells. The areal size of the array must increase slightly $(\sim 10 \%)$ to account for the higher operating temperature of the concentrator cells while collecting sufficient solar flux. The concentrators lower the mass of the power system by about $6 \%$, and they can potentially lower the cost of arrays by replacing high-cost solar cells with lower cost reflective elements. It is difficult to assess this cost savings because the concentrators will add complexity that will have some associated costs. The pointing requirements needed to maintain full illumination were sufficiently lax to maintain the ability for no-roll steering, so no other changes to the baseline configuration were required. The mass breakdown for this variant is shown in Table 3 as Case IV.

Our final power variation assessed the impact of using a nuclear reactor instead of a solar array. This concept vehicle is shown in Fig. 5. The $300 \mathrm{~kW}$ of electrical power is created by a uranium-fueled fission reactor coupled to two $100 \%$ redundant Brayton power converters. The Brayton alternators deliver three-phase AC power at $480 \mathrm{~V}$ that is rectified in a direct-drive unit to power ten $36-\mathrm{kW}$ Hall thrusters generating $2640 \mathrm{sec}$ of specific impulse with xenon propellant contained in a single, 3-m-diameter COPV tank. A simple body-mounted and single-hinge deployable radiator system dissipates the Brayton waste heat. A telescoping boom provides separation between the reactor and the payload, and a truncated cone radiation shield with a $22^{\circ}$ half angle protects the vehicle and crew from nuclear radiation. As shown in Table 3, Case VIII, the nuclear power system is heavier than the solar power system, but this mass is compensated by a reduced xenon propellant mass enabled by the higher Isp. Even with the higher Isp, the nuclear vehicle meets the trip time requirement, primarily because it provides continuous thrust even during the occulted portion of the spiral out. Development (after technology readiness level (TRL) 6) and recurring costs are expected to be about $30 \%$ higher than a comparable solar electric vehicle, but development costs incurred for this mission could be directly applicable to higher power missions needed for cargo and crewed missions to Mars for instance. ${ }^{10,11}$

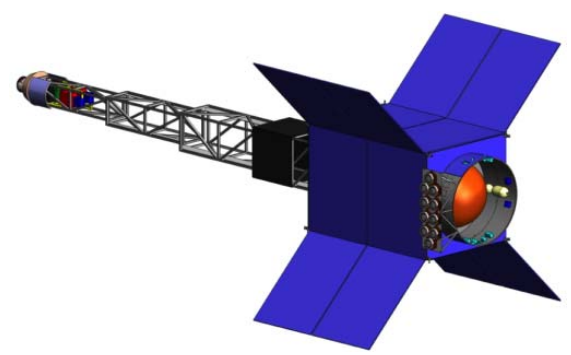

Figure 5. Nuclear electric concept vehicle. 


\section{B. Propulsion Trades}

The following four propulsion parameters were studied to determine vehicle mass and cost impacts: thruster power level, power processor design, propellant tank size, and propellant storage conditions.

The baseline concept vehicle described in Section II.C used ten 30-kW-rated Hall thrusters. No spares were provided since losing a thruster string will only reduce the coast time for the piloted portion of the trip. Direct-drive units were connected to each thruster. No cross-strapping was considered. Four of the thrusters were gimbaled and mounted at the perimeter of the stage's bus structure to augment the attitude control provided by the RCS thrusters; the remaining six were statically mounted and clustered in the center as shown in Fig. 6(a). Ten direct-drive units (one for each thruster) were mounted on the inside of the bottom deck. The first propulsion variant increased the size of each thruster to provide nominal operation at $50 \mathrm{~kW}$. Six of these thrusters, plus one spare, and the associated seven direct-drive power processors, could easily fit within the available space and mass constraints so no other changes to the baseline configuration were needed. A spare was included because an engine-out condition using only six thrusters would yield a trip time that exceeds allowable mission constraints. This variant is shown in Fig. 6(b) and the resultant vehicle mass is shown in Table 3 as Case V. Note that the inert mass increased slightly as compared to the baseline, primarily because a spare thruster is required. Although there is no mass benefit, there may be a cost savings associated with using fewer units because of reduced qualification testing and parts count.

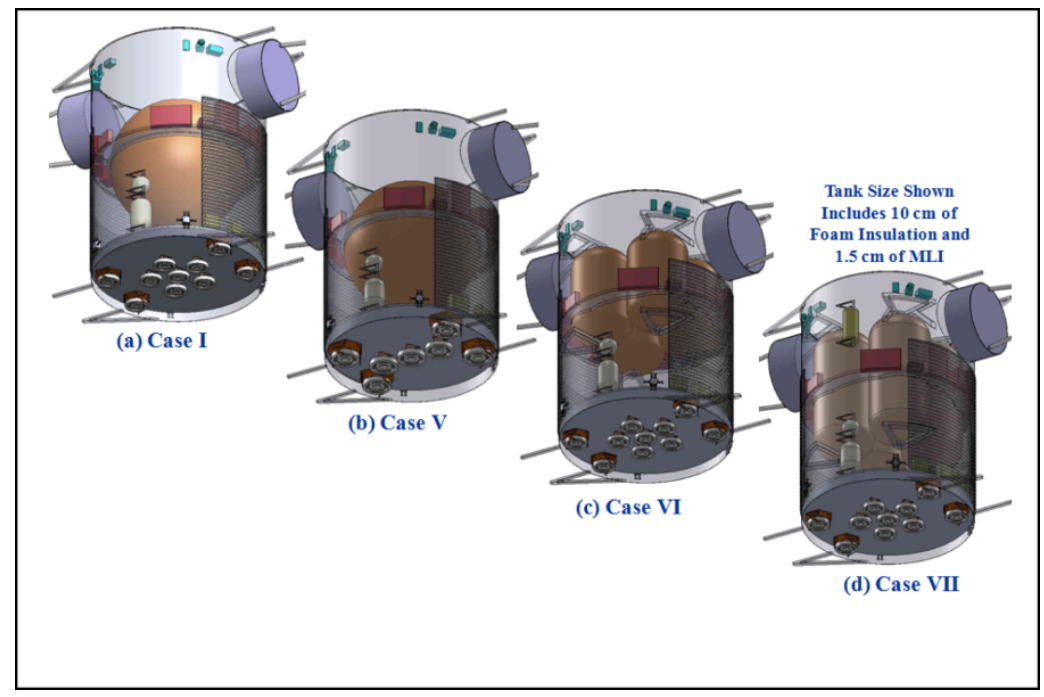

Figure 6. Propulsion variants.

Direct-drive power processing units (DDUs) were used in the baseline configuration. The use of DDUs is only possible when the arrays produce a voltage within the operating range of the thrusters, nominally 300 to $600 \mathrm{~V}$. Outside of that range, conventional power PPUs are required. The use of PPUs instead of DDUs increases the system mass as is shown in Table 3, Case II. The increased mass arises primarily from adding isolation transformers to regulate the voltage generated by the solar arrays to match that needed by the thrusters, and bigger radiators to reject the additional heat generated by the less efficient PPUs ( $95 \%$ efficient PPU vs. $99 \%$ efficient DDUs). PPU mass was assumed to be $100 \mathrm{~kg}$ each, although they may be as low as $88 \mathrm{~kg}$. The mass difference of $12 \mathrm{~kg}$ each is small relative to the vehicle mass. Note that while the DDUs reduce system mass, they potentially increase operational risk because of their inability to operate over wide voltage swings.

To save mass, the baseline configuration used a single 3-m-diameter spherical COPV tank to store the xenon propellant as a supercritical gas at 1200 psia. A tank this large may be difficult to fabricate, so we studied the impact of replacing the single tank with four smaller COPV cylindrical tanks. To fit into the baseline stage structure, the maximum allowable diameter for each of the four tanks is $1.62 \mathrm{~m}$. The overall length of the tanks is $2.83 \mathrm{~m}$, easily fitting within the baseline structure as shown in Fig. 6(c). Additional structure was added to the inside of the stage structure to handle the polar boss tank mounting for the tanks. As shown in Table 3, Case VIa, this design did not meet mission mass requirements primarily because of the increased surface area (and hence mass) to store the same volume, increased wall thickness in the cylindrical portion of the tanks, and additional structure. Increasing the specific impulse of the thrusters to $2100 \mathrm{sec}$ can compensate for this mass overrun at the expense of piloted trip time. 
To reduce the mass required by the four cylindrical supercritical tanks, active cooling was added to reduce the tank pressure and thus reduce the required wall thickness. The maximum allowable diameter for each of the four tanks was kept at $1.62 \mathrm{~m}$, allowing for $10 \mathrm{~cm}$ of foam insulation and $1.5 \mathrm{~cm}$ of multilayer insulation. This increased the overall tank length to $3.79 \mathrm{~m}$, and required the addition of two small buffer tanks and associated mounting structure (Fig. 6(d)). No other changes to the baseline configuration were needed. This configuration was more massive than the single tank configuration, but fit within the mass allocation as shown in Table 3, Case VII.

\section{Results}

A summary of the mass breakdown for the baseline SEP stage and each propulsion and power variant is shown in Table 3. Out of the eight variations studied, only two designs could not fit within the mass and volume constraints levied by the mission using thrusters operating at $2000 \mathrm{sec}$ Isp: the $120 \mathrm{~V}$ bus voltage and the four supercritical xenon tanks. The mass associated with a $120-\mathrm{V}$ spacecraft bus was high because the bus harness mass was eight times larger than that required for the high-voltage $(300-\mathrm{V})$ system, and the use of conventional power processing units was required to boost the voltage to levels required by the electric thrusters. Multiple smaller tanks increased mass because the tanks were heavier. Bus voltages as low as $120 \mathrm{~V}$ and supercritical xenon storage in smaller tanks can, however, be used for this mission when the specific impulse is boosted by $5 \%$ to $2100 \mathrm{sec}$. The crewed portion of the trip still meets the stated requirement of 400 days needed to keep human exposure to harmful radiation within allowable limits. As is usually found with electric propulsion, the Isp "knob" can be tuned to meet the launch mass at the expense of trip time. For this specific mission, the Isp tuning was fairly small (hundreds of seconds) and the required mission times could be met. However, once abort scenarios are considered, this ability to increase specific impulse may not be possible.

Each of the other variants can accomplish the mission within mass and volume limits, subject to the caveat stated at the outset: contingency operations were not considered and thus these are only design concepts, not true designs. Given that, the relative benefits of the various trades are summarized in Table 5. In this table, technologies in the first column (technology "A") are compared to the technologies in the second column (technology "B") for vehicle mass, technology development cost to TRL 6, flight hardware costs (nonrecurring and recurring, assuming TRL 6 is achieved), and technical risk. The relative indicators include " $\mathrm{HH}$ " representing a very large mass savings of technology "A" over technology "B" and "H," "M," and "L" for large, medium, and small mass savings. Development costs are designated as low, medium, or high representing additional costs required to bring technology "A" to TRL 6 relative to technology "B." Flight hardware costs are marked "+" to indicate a probable savings and "- " to indicate more expensive hardware for technology "A" as compared to technology "B." The technical risk of developing technology "A" relative to technology "B" to TRL 6 is denoted high, medium, or low for substantially more risk, more risk, and nominally the same risk.

From this summary, one can see that the largest potential mass savings may be realized by four technologies: a direct-drive architecture, high-voltage solar arrays, a large in diameter spherical propellant tank, and an active cooling for the xenon propellant. Note that high-voltage operation is a necessary condition for direct-drive architectures, and the combination of the two provides over a $4 \mathrm{mt}$ mass savings.

Moderate mass savings can be realized by increasing photovoltaic cell efficiency to $37 \%$. The inert mass difference is small for $2 \mathrm{X}$ concentrator arrays and $50-\mathrm{kW}$ Hall thrusters, and the difference between the launch mass of the nuclear and solar vehicles is also small.

Table 5. Mass, cost, and risk comparisons of power and propulsion technologies.

\begin{tabular}{|c|c|c|c|c|c|c|}
\hline Technology "A"as compared to... & ...Technology "B" & $\begin{array}{l}\text { Vehicle Mass } \\
\text { Impact }(\mathrm{kg})\end{array}$ & $\begin{array}{l}\text { Mass } \\
\text { Impact }\end{array}$ & $\begin{array}{l}\text { Development } \\
\text { Cost }\end{array}$ & $\begin{array}{c}\text { Flight H/W } \\
\text { Cost }\end{array} \mid$ & $\begin{array}{c}\text { Technical } \\
\text { Risk }\end{array}$ \\
\hline 300 VDC Power Bus Feeding DDU & 120 VDC Power Bus Feeding PPU & 4394 savings & $\mathrm{HH}$ & med & + & $M$ \\
\hline 300 VDC Power Bus Feeding PPU & 120 VDC Power Bus Feeding PPU & $\underline{2457 \text { savings }}$ & $\mathrm{HH}$ & med & + & M \\
\hline $\begin{array}{c}\mathrm{DDU} \\
\text { (requires }>=300 \mathrm{VDC} \text { Power Bus) }\end{array}$ & PPU@ @ 300 VDC & 1937 savings & H & low & + & M \\
\hline One 3m COPV Xe tank & Four $1.6 \times 2.8 \mathrm{~m}$ COPV Xe tanks & 2797 savings & $\mathrm{HH}$ & med & - & $\mathrm{H}$ \\
\hline Active Cooling for Xe Tanks & Passive Cooling for Xe Tanks & 1693 savings & $\mathrm{H}$ & low & - & L \\
\hline 37\% PV Cell Efficiency & $\underline{29 \%}$ PV Cell Efficiency & $\sim 879$ savings & M & med & & $\mathrm{H}$ \\
\hline$\underline{2 X \text { concentrator solar array }}$ & Planar solar array & $\underline{383 \text { savings }}$ & $\mathrm{L}$ & low & + & $\mathrm{L}$ \\
\hline$\underline{50 \mathrm{~kW} \text { Hall Thrusters (1 spare) }}$ & $\underline{30 \mathrm{~kW} \text { Hall Thrusters (no spare) }}$ & 211 increase & $\mathrm{L}$ & low & + & $\mathrm{L}$ \\
\hline $\begin{array}{c}300 \mathrm{~kW} \text { Fission Reactor with Bravton } \\
\text { Power Converters }\end{array}$ & $300 \mathrm{~kW}$ Planar Solar Array with Direct Drive & $\underline{361 \text { increase }}$ & L & high & - & L \\
\hline
\end{tabular}


Table 6. Technology readiness levels of power and propulsion technologies needed for 300-kW-class electric propulsion spacecraft.

\begin{tabular}{|c|c|c|c|}
\hline Technology & TRL & Critical Need & SOA \\
\hline $\begin{array}{l}300 \mathrm{~kW} \text { Planar Arrays/30 kW Hall Thrusters/Direct Drive } \\
\text { System }\end{array}$ & 3 & System level testing & \multirow{2}{*}{$\begin{array}{l}9 \mathrm{~kW} \\
\text { (AEHF) }\end{array}$} \\
\hline $30 \mathrm{~kW}$ Hall Thruster/PPU system & 5 & System level testing & \\
\hline $30 \mathrm{~kW}$ Hall Thruster/DDU system & 3 & System level testing & \\
\hline $30 \mathrm{~kW}$ Hall Thrusters & $5 / 6$ & $\begin{array}{l}\text { Environmental testing needed; Performance testing under } \\
\text { engine-out conditions; Improved life at higher Isp }\end{array}$ & \multirow{3}{*}{$\begin{array}{l}4.5 \mathrm{~kW} \\
(\mathrm{BPT}-4000)\end{array}$} \\
\hline $50 \mathrm{~kW}$ Hall Thrusters & 5 & Environmental testing needed; Life testing data & \\
\hline $30-50 \mathrm{~kW}$ Power Processing Units (120 V input) & 3 & & \\
\hline $30-50$ kW Power Processing Units ( $300 \mathrm{~V}$ input) & 3 & Reliable high voltage power electronics & none \\
\hline Direct Drive Unit & 3 & Requires system level testing to reduce operational risks & $2 \mathrm{~kW}$ Lab test \\
\hline Power Distribution Unit (120 V) & 6 & & \\
\hline Power Distribution Unit (300 V) & 5 & & \\
\hline 300 kW Planar Solar Arrays (120 V) & $3 / 4$ & \multirow{2}{*}{$\begin{array}{l}\text { Deployable, stiff, high strength/mass structures; } \\
\text { Low stowed volume }\end{array}$} & \multirow{2}{*}{$\begin{array}{l}30 \mathrm{~kW} \\
\text { Honeycomb } \\
\text { panels }\end{array}$} \\
\hline 300 kW Planar Solar Arrays (300 V) & $3 / 4$ & & \\
\hline $300 \mathrm{~kW}$ Concentrator solar arrays $(2 \mathrm{X})$ & $3 / 4$ & $\begin{array}{l}\text { Deployable, stiff, high strength/mass structures; } \\
\text { Reliable, low cost concentrators }\end{array}$ & $\begin{array}{l}\text { Flight demo } \\
\text { coupons }\end{array}$ \\
\hline $29 \%$ Efficienct PV Cells & $5 / 6$ & \multirow{3}{*}{ Radiation tolerant, low cost, cellyblanket integration } & IMMM TJ \\
\hline $33 \%$ Efficienct PV Cells & $5 / 6$ & & IMM TJ \\
\hline $37 \%$ Efficienct PV Cells & 3 & & IIMM $4^{*} \mathrm{~J}$ \\
\hline $3 m$ COPV Xe tank & 2 & Large structure autoclave & \multirow{2}{*}{$\begin{array}{l}1.2 \mathrm{~m} \text { diam } \\
\text { COPV }\end{array}$} \\
\hline $1.6 \mathrm{~m} \times 3.8 \mathrm{~m}$ COPV Xe tank & 3 & Fabrication & \\
\hline Active Cooling for Xe Tanks & 6 & Application to Xe tanks & \\
\hline 300 kW Fission Reactor (1100 K) & 4 & System level testing & \multirow{2}{*}{$\begin{array}{l}500 \mathrm{~W} \\
\text { SNAP-10 }\end{array}$} \\
\hline 150 kW Brayton Power Converters & 4 & System level testing & \\
\hline Radiators & 6 & & \\
\hline
\end{tabular}

The current TRLs of the power and propulsion technologies employed during this study is shown in Table 6, together with a listing of critical needs still left to develop for this application and the current state of the art.

A cost analysis showed that the largest single contributor to the cost of the SEP stage is the solar arrays, and the largest contributor to the cost of the arrays is the cell/interconnect/coverglass assemblies and their integration into the array blanket (Fig. 7). These elements constitute nominally 33\% of the stage's flight hardware cost. Reducing this cost is by far the largest means to reducing the cost of this vehicle. One way to do this is to use concentrator arrays, which should provide cost savings by replacing high-cost photovoltaic cells by lower cost reflective elements. The $2 \mathrm{X}$ concentrator did not impose pointing requirements sufficient to require additional control hardware, so the savings should be equal to the difference in cost between the installed reflective elements and half of the installed solar cells. Increasing the efficiency of the cells will reduce costs by reducing the number of cells. However, lower efficiency cells may cost substantially less than higher efficiency cells, so there may be no net benefit or the lower cost cells may produce a lower vehicle cost.

Further savings should be realizable by using direct-drive power processors because they eliminate the need for a number of high-voltage components. The cost of a single, large xenon tank will be higher than the smaller tanks, but the large mass savings may warrant the expense. The cost of developing a nuclear reactor from TRL 6 and deploying it is estimated to be roughly $30 \%$ higher than the corresponding solar arrays, but this cost could be justified because the foundation of such a system would provide for future missions to Mars. 


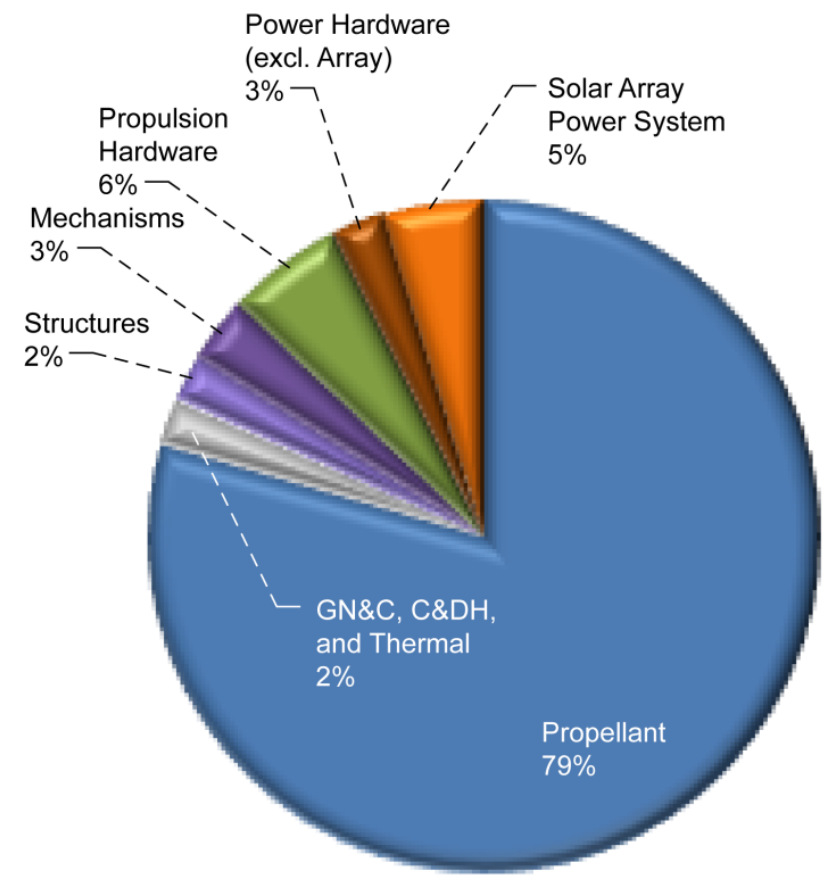

Baseline SEP Stage Wet Mass

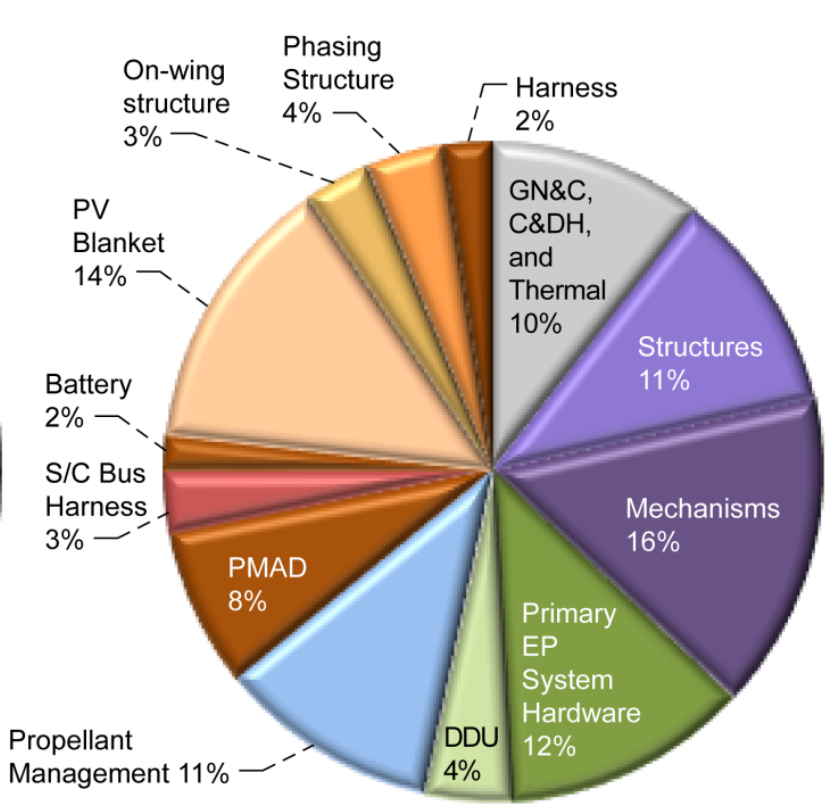

Baseline SEP Stage Inert Mass

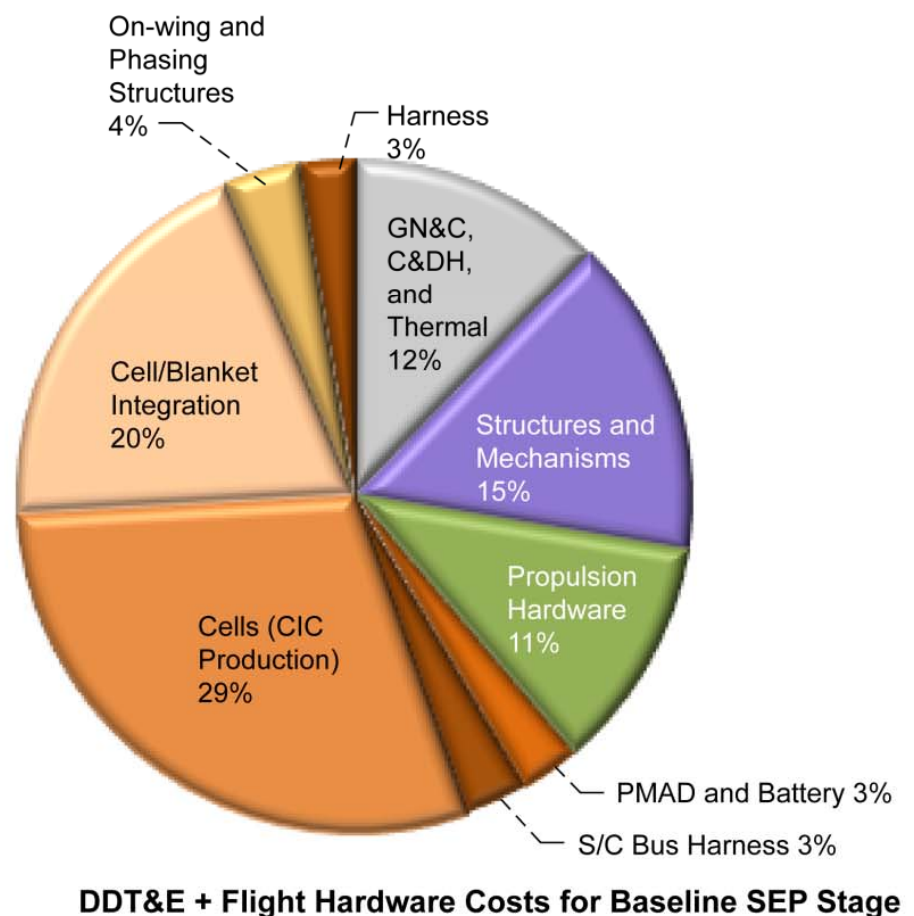

Figure 7. Mass and cost breakdown for baseline vehicle (Case I). 


\section{Conclusion}

A 300-kW-class SEP vehicle concept was created to assess the system-level mass and cost impacts of power and propulsion technologies. The following technologies were assessed: electric thruster power level, power processing architecture, propellant storage, bus voltage, solar array concentration, solar cell efficiency, and power generation (solar vs. nuclear).

We found that this specific design reference mission could not be accomplished without using a high-voltage bus (nominally $300 \mathrm{~V}$ ) unless the Isp was increased and the trip time was subsequently increased. Increased Isp's can be used to reduce mass instead of adopting the other technologies considered in this study but may not be feasible in abort scenarios and would not reduce recurring costs.

The technologies able to most significantly reduce mass are a high-voltage solar array and power bus, direct drive, and large xenon tanks. Each of these require technology development to bring to flight readiness.

Moderate mass savings could be realized by storing the xenon propellant as a liquid and by increased photovoltaic cell efficiency. The $2 \mathrm{X}$ concentrator arrays and $50-\mathrm{kW}$ Hall thrusters provide at most a small mass improvement, and the difference between the launch mass of the nuclear and solar vehicles is also small.

By far the largest contributor to the cost of the arrays is the cell/interconnect/coverglass assemblies and their integration into the array blanket, which constitute nominally 33\% of the stage's flight hardware costs (from TRL 6 to flight hardware). Direct-drive processors can also reduce costs by eliminating a number of high-voltage components. A nuclear reactor would cost nominally $30 \%$ more than solar arrays, but the cost could be justified because of the foundation such a system would provide for future missions to Mars.

There are limits to the results of these studies. If a different mission is selected, the results will change. If contingency operations are factored in, the results will change. A different suite of technologies could also be considered, again possibly changing the results. However, we believe that these results are representative and provide insight into the relative benefits of key power and propulsion technologies for solar electric vehicles of this class.

In addition to understanding the system-level benefits of particular technology advancements as summarized in Table 3, the feasibility, cost, and time to develop must also be considered when determining investment priorities. We believe that all of the technologies listed in Table 6 have a feasible path for development, and the time needed to bring them to TRL 6 scales roughly inversely with their current TRL level, excluding the time needed for life testing. Relative costs for both technology development and flight hardware are estimated in Table 5. A robust technology development program that attacks any subset of these technologies will substantially improve the state of the art of electric propulsion stages, laying the groundwork for a new capability for commercial and exploration opportunities in space.

\section{Acknowledgments}

The authors gratefully acknowledge the efforts of the entire COMPASS team at the NASA Glenn Research Center: Les Balkanyi, Anthony Colozza, John Dankanich, Jon Drexler, Robert Falck, James Fincannon, James Fittje, John Gyekenyesi, Geoffrey Landis, Mike Martini, Tom Packard, Thomas Parkey, Paul Schmitz, Jeff Woytach, Joe Warner, Glenn L. Williams, Anita Tenteris, and especially Melissa McGuire and Carl Sandifer for their diligent efforts in keeping things straight. Thanks also go to Sal DiStefano at the Jet Propulsion Laboratory and to the Exploration Technology Development and Demonstration Program within the Exploration Systems Mission Directorate.

\section{References}

${ }^{1}$ NASA Exploration Systems Mission Directorate presentation, "Human Space Exploration Summary,” http://www.nasa.gov/ pdf/525162main HEFT Final Brief 508 20110309.pdf, January 2011. [cited 19 Aug 2011].

${ }^{2}$ S. Oleson, et al., "COMPASS Final Report: Exploration Technology Development and Demonstration (ETDD) Program Design Reference Mission (DRM) \#1: Piloted Solar Electric Propulsion (SEP) to a Near Earth Orbiting (NEO) Asteroid,” NASA CD-2011-56 (to be published as a NASA TM).

${ }^{3}$ J.R. Brophy, R. Gershman, N. Strange, D. Landau, R.G. Merrill, T. Kerslake, "300-kW Solar Electric Propulsion System Configuration for Human Exploration of Near-Earth Asteroids," AIAA-2011-5514, Presented at the 47 ${ }^{\text {th }}$ AIAA/ASME/ SAE/ASEE Joint Propulsion Conference, August 1, 2011.

${ }^{4}$ Collaborative Modeling for Parametric Assessment of Space Systems http://www.grc.nasa.gov/WWW/compass/ [cited 19 Aug 2011].

5"Rapid Calculation of Spacecraft Trajectories Using Efficient Taylor Series Integration," NASA Tech Briefs, Jan. 1, 2011 http://www.techbriefs.com/component/content/article/9031 [cited 19 Aug 2011]. 
${ }^{6}$ The In-Space Propulsion Technology Project Low-Thrust Trajectory Tool Suite: MALTO http://ntrs.nasa.gov/archive/nasa/ casi.ntrs.nasa.gov/20080047350_2008047178.pdf [cited 19 Aug 2011].

${ }^{7}$ D. Hoffman, et al., "Concept Design of High Power Solar Electric Propulsion Vehicles for Human Exploration," Presented at the $62^{\text {nd }}$ International Astronautical Congress, Cape Town, South Africa, Oct 3-7, 2011, IAC-11-D2.3.5.

${ }^{8}$ L.A. Capadona, et al., "Feasibility of Large High-Powered Solar Electric Propulsion Vehicles: Issues and Solutions," AIAA, Presented at the AIAA Space 2011 Conference, Long Beach, CA, September 27-29, 2011.

${ }^{9}$ S. Oleson, et al., "COMPASS Final Report: Exploration Technology Development and Demonstration (ETDD) Program Design Reference Mission (DRM) \#2: Piloted Solar Electric Propulsion (SEP) to a Near Earth Orbiting (NEO) Asteroid Photovoltaic and Propulsion Trades," NASA CD-2011-60 (to be published as a NASA TM).

${ }^{10}$ L. Mason, "Evolutionary Development Path for Viable Nuclear Electric Propulsion Systems for Exploration," presented at the $47^{\text {th }}$ AIAA/ASME/SAE/ASEE Joint Propulsion Conference, August 1, 2011.

${ }^{11}$ J.H. Gilland et al., "MW-Class Electric Propulsion System Designs for Mars Cargo Transport," presented at the AIAA Space 2011 Conference, Long Beach CA, September 27-29, 2011. 